\title{
Russian as Native, Non-native, one of Natives and Foreign Languages: Questions of Terminology and Measurement of Levels of Proficiency
}

\author{
Ekaterina L'vovna Koudrjavtseva ${ }^{1}$, Daniya Abuzarobna Salimova ${ }^{2} \&$ Ludmila Anatolievna Snigireva $^{3}$ \\ ${ }^{1}$ Institute of Foreign Languages and Media Technology of the University of Greifswald, Germany \\ ${ }^{2}$ Russian Language Department, Kazan Federal University, Yelabuga, Russia \\ ${ }^{3}$ National University of Ireland, Maynooth, Ireland \\ Correspondence: Ekaterina L’vovna Koudrjavtseva, Hägerfelder Weg 4, Gutow, 18276, Germany. E-mail: \\ Ekoudrjavtseva@yahoo.de
}

Received: December 20, 2014 Accepted: March 27, 2015 Online Published: May 22, 2015

doi:10.5539/ass.v11n14p124 URL: http://dx.doi.org/10.5539/ass.v11n14p124

\begin{abstract}
The 21st century has brought globalization of people's lives and education. Dramatic economical, political and natural cataclysms has made our planet's population mobile and that concerns not only highly developed countries but also so called the third world countries. While moving and changing their places of residence people bring with them their native language, their culture, knowledge and experience. They also bring to their new county of residence their own perception about communication, both an inner communication and an intercultural one. Bulat Okudzhava said in one of his poems, "To understand each other is a sacred science", and today this approach to communication becomes a vital necessity in everyday life, in the sphere of science and education, in real space as well as in the virtual one. While people actively learn foreign languages with approved status, minor languages become suppressed in spite of the fact that the population - bearers of these minor languages are quite numerous and these bearers should be taken into consideration. But this problem is likely to be referred to politics. In the frames of practical educational activities we deal with various problems. One of them quite often causes obstacles not only in organizing of the methodically correct educational process but also in its monitoring process. Its impact on marking the final results, on achieving targeted competences all these are the subjects of correct terminology. To be more precise - correlation of terminology that is accepted in Russian Federation and in the world (in the first place in Europe, the USA, Israel).
\end{abstract}

Keywords: language as native, language as non-native (one of native), family language, the foreign language, natural two-and multilingualism, national component, migration, global educational space

\section{Introduction}

Hundreds of dissertations, textbooks, and scientific articles have been dedicated to the study of Russian as a foreign language. (For example, we remember the textbook written in the 1960s specially for Americans by Alexander Lipson and Stephen J. Molinsky).

We have written earlier about differentiation of the terms "Russian as non-native" (RAN), "as one of native (another native)"(RAAN) and "Russian as foreign" (RAF) (Berseneva \& Kudryavtseva, 2013) earlier. Here we will revise once again only the key moments: 1) Is terminological division on the basis of exclusively territorial sign (geographical distribution of Russian) possible? It is unlikely, as in that case we can and have to speak about RAN and RAAN on the territory of the former Soviet republics practically as about the synonymous phenomena opposed to RAF (which is gradually taking place of RANN and RAAN) and Russian as native.

In the national districts of the Russian Federation where Russian is the state language, we traditionally speak about "Russian as native" (RAN) though, actually, its even subjectively perceived position (the number of communications occurring in life and used in mass media not in Russian, but in local national languages and in Russian too as well as in other languages) RAANin Tatarstan, the Yamalo-Nenets Autonomous Area and in Udmurtia is various (taking into consideration a position of the Tatar, Nenets and Udmurt languages respectively) and the attitude of representatives of indigenous peoples towards him is various. 
Migrants - from the Russian Federation who move to foreign countries and from the CIS countries and the former republics of the USSR who move to the Russian Federation - turn out to be in a "grey" field, in other words in a gap caused by "territorial" partitioning.

In accordance with the Russian educational system all children of migrants living in the Russian Federation have to get their education in Russian and an ultimate goal for them is to pass Unified State Examination. Therefore, requirements to them after finishing school are the same as to the RAN carrier, without taking into account their national languages and cultures (according to Federal State Educational Standard (FSES) - "ethnocomponent"). And that has a crucial impact on educational process. When they enter the educational system, they sometimes face the conditions, that are considered to be functioning as propaedeutic courses or introduction courses of RAF (for example, "Schools of Russian" in Moscow).

The former USSR and the CIS children who migrate with their parents to other parts of the world often continue to be taught in the centers of additional/supplementary education where RAN is based on materials and reduced programs of Russian schools. The reduction reaches two thirds of the entire amount of the material (up to 40 hours per year), despite the fact that their educational needs (Russian school-leaving certificate, Unified State Exam, etc.), the level of their communication in Russian and the level of proficiency in Russian differ significantly from their Russian peers. At the same time those teenagers with Russian as their mother tongue (2L1), i.e. "heritagers" (heritage language) become so-called "early recessive bilinguals" i.e., they have become bilinguals since childhood, but one of the languages regresses (the process of "fossilization" / "Fossilisierung" by S. Montrul). Can that happen with the native language? With a foreign one as non-native - yes, that can happen. As far as the native language is concerned, the problem is complex. Scholars' and researchers' opinions in this respect are divergent (Montrul, 2008).

At last, the concept of "a native language" depends on temporary and legal parameters in different countries of the world (the opinion of carriers, and also their level of proficiency in the language aren't taken into consideration.). For example, at university of St. Gallen (Switzerland) the native language is considered to be the one in which the student received the school-leaving certificate. If a learner studied in different countries, the native language is considered to be that one in which the learner studied at least for 8 years.

2) Another way of learners' division into categories of RAN, RAF, RANN, RAAN is the way of an assessment of their lexical, grammatical, auditional, reading and speaking competences. This method is time-tested, and working for many languages in many countries of the world (Testing Russian As Foreign (TRAF) is based on levels of the European language portfolio and actually is Unicertili TOEFL of "the Russian sample").

\section{Methodology}

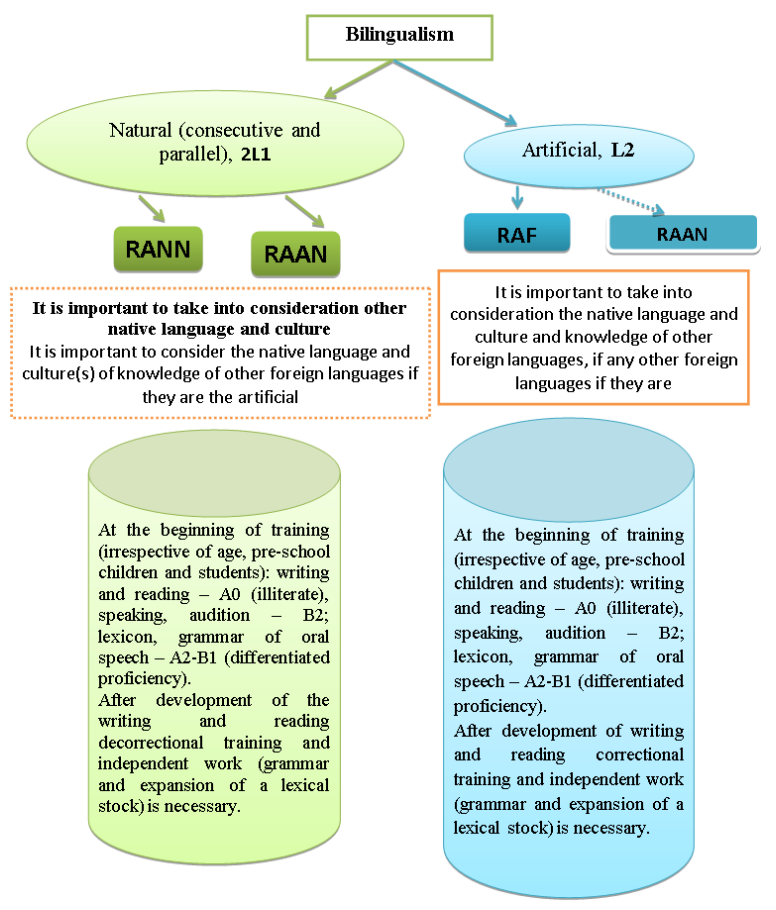

Figure 1. Realization of bilingualism in educational process. 
Let's look how levels of the European language portfolio are corresponding to the concepts necessary for a choice of a technique, finding so called "key" to each learner and choosing of an individual training and educational process : RAN, RAF, RAAN, RANN.

Concerning RANN carriers (Chechens, Georgians and Abkhazians, migrants from the republics of Central Asia) with the same basic experience (except for one - the personal relation to the language and its carriers inherited from the senior, previous generations), - the similar accelerated growth of communicative competence in Russian wasn't observed.1 It's important to notice that we mean communicative competence with all its components, if to take into consideration the five "key competences" accepted in 1996 in Bern (Hutmacher, 1996, p. 38) and defined as bridges between knowledge and ability to use it.

Thus $2 \mathrm{~L} 1=2$ native languages (two "first languages" - the term accepted in the world for a natural bilingualism; division into non-native and another native or one and another native languages does not exist). To illustrate that we can give examples when RAAN carriers (for example, "Russian Germans" who speak Russian at home to family members, but are not competent neither in writing, nor in reading in Russian), after having studied for 2 semesters at the course for beginners (A0, with further aim of A1), continued at the advanced courses (B1 and even B2) and successfully passed examination in the end. All that was achievable on the following conditions: an individual approach during the training and educational process from a teacher's side (the correctional, "filling in" training) and purposeful self-education.

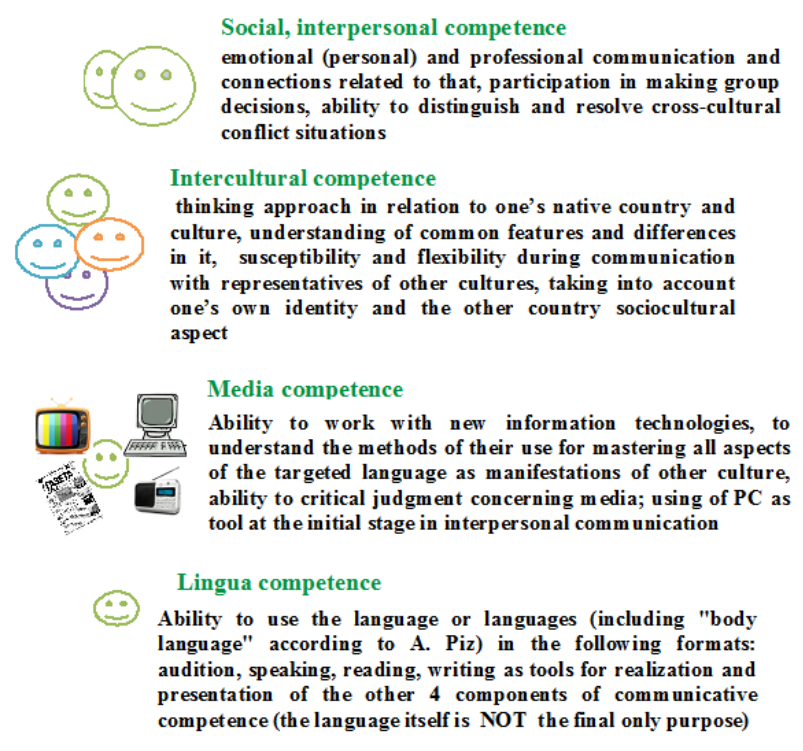

Figure 2. Components of communicative competence (the terminology accepted in the Russian Federation like "linguamultimedia competence" shows only one part of this structure and leads to a wrong understanding of its functioning)

Variants of realization of the abilities described above, opportunities and readiness (desire) to master (RANN / RAAN) and to acquire (RAF) Russian, - are non-limited. In our gained experience it is easy to find situations when the RAF carrier is at the level of A1 (linguistic competence), but at the same time the knowledge of Russia, its history, culture, life was much more profound and extensive than of those who were the carriers of Russian as native and were at the same age category. In the audience there was also so-called "the Russian foreigner" knowing Russian as non-native at the level of B2 (linguistic competence), but due to specific private circumstances not using it in daily communication and didn't seek for obtaining information in Russian from original Russian sources. Such examples are well demonstrated in the article "The Russian Language in Ireland: the Dialogue of Cultures" (Snigireva, 2013, p. 136).

Therefore, the level of proficiency of communicative competence (A1-C2) of the linguistic component does not demonstrate the general level of communicative competence and cannot be considered as the only ground for its assessment.

Based on of the Figures provided above, we could see that all components of communicative competence have a direct connection with the identity of the learner. We also saw that while defining the differences between RAF 
and RAON we incline towards the personal relation between a learner / speaker and the language as a generated concentration of the national consciousness / world perception and the carrier of ethnocultural content. In the end all the components of communicative competences will be shown to you, while a learner/speaker is introducing himself. It could be either, "Hi, I am Daniel", or "Good afternoon, my name is Daniel Vilfridovich", or even "My name is Daniel. I am very pleased to meet you" ...

\section{Discussion}

Many scientists were engaged in problems of relationship between ethnic culture and the language itself. The ideas of A.v. Humboldt gained the greatest fame. "Studying of the language opens for us, besides of its use as such, analogy between the person and the world in general and between each nation which is definitely expressing itself in the language" (Gumboldt, 1964, p. 348). According to Humboldt's ideas, any language is a heritage storage of national spirit, culture, it is "the joined integrated spiritual national energy, wonderfully imprinted in certain sounds" "neither any concept can exist without a language, nor any subject can be taken by us to our insights without it"(Gumboldt, 1964, p. 349). "There is a unique world observation in each language. A human being lives surrounded by subjects, can feel them the way the language describes them. Each language makes a circle around the nation to which it belongs, and to leave that circle is possible when a person enters a circle of another language" (Gumboldt, 1964, p. 80), therefore "the differences between languages represent something bigger, than simply signs' variations. In fact, different languages in their essence and influence on knowledge and feelings, are actually various worldviews" (Gumboldt, 1964, p. 370). This issue was further researched in its development in Russia in the XIX century, and especially during the last decades both in the Russian and foreign linguistics. According to Rafieyan et al., "familiarity with and awareness of the cultural features of the targeted language community and the awareness of the differences between source language and targeted language cultural features really facilitates learners' understanding of the targeted language" (Rafieyan et al., 2013, p. 131).In other words, "language, defining the type of consciousness, predetermines the learner's attitude (we take a situation when Russian is language of communication of the older generation)" (Berseneva \& Kudryavtseva, 2013, p. 182). "As an immigrant.... familiarity with the official language, that immensely valuable and essential tool of communication, has been a determining factor in the process of acculturation" (Imberti, 2007, p. 71):

If to show the mentioned above in a table, we get the following:

Table 1. The levels of the European language portfolio for the native speakers as a foreign language: A1 - C2 and the levels distinguished according to the subjective relation of the native speaker to the language: RAAN, RANN (RAN and RAF usually become objective corresponding to the individual biography of the native speaker)

The levels of the European language portfolio for the The levels distinguished according to the subjective native speakers as a foreign language: A1 - C2 relation of the native speaker to the language: RAAN, RANN (RAN and RAF usually become objective corresponding to the individual biography of the native speaker)

First of all, the levels of the linguistic component of The levels of socio-cultural, ethno-cultural and communicative competence are required; the other I-component of communicative competence are taken into components are not taken into consideration while testing consideration

Knowledge of the language rules and speech standards Skills of situational use of the language in the context of the native speakers' culture.

Training and self-training. Learning of the language using Education (self-education) and/or training. Familiarization models/ patterns, standards or/and learning of the language samples/ patterns

External environmental motivation (study, work, status, Internal and external motivation. etc).

Evaluation /marking of the vocabulary, grammar, writing, Assessment or complex indivisible attitude to the language reading, listening, speaking skills.

Possible division into components and their objectification takes place through the assessment tasks, evaluation/marking the course and results of communication with all participants in a particular situation)

Knowledge of the language norms is primary $\quad$ Feeling of the language is primary

Language as a purpose $\quad$ Language as a tool

Objective assessments $\quad$ Subjective self-assessment






Figure 3. Types of bilingual relations/attitudes to the Russian language ("linguistic self-identification" and "Every language contains its own naïve picture of the world including its own ethnopsychology" (Apresjan, 1974,5-32) and "doubleness" experienced by bilinguals : "that of a neither/nor identity, rather than a both/and identity, which had also been referenced as " outsider-ness" in each of her contexts."(Burck, 2004, 323) and "cultural borderlands" (Rosaldo, 1989, p. 19)

Language teaching methodology should be based on the sum of all these components, and therefore should use the methods and techniques of ethno-cultural content in the most active way. For example, using the method of online tandems (Kudryavtseva, 2013a; Kudryavtseva, 2013b).

In verbal communication differences between RAAS and RANN carriers appear more clearly than in writing that is restricted by standards and norms. For RAAN it is characteristic to accept the language and culture as integral parts of a speaker. They can be either his/her own or acquired. The following issues can be taken as characteristic: 1) the richness and variety of forms (corresponding to the level of proficiency and in accordance with the European Language Portfolio); 2) the willingness to continue the dialogue / monologue, even if there are difficulties (if necessary in such cases repeated requests for clarification, assistance in finding lexemes is asked for); 3) positive emotional attitude; 4) active position (offer / request for information / action); 5) creation of new words; 6) suppression or absence of "fear of communication" with native speakers and some others.

Whereas in the case of the perception of the language (and culture of its carriers) as "non-native / externally imposed" (alien) the following issues are present: 1) so-called "blockage", first of all, of the spoken language; the wish to stop the conversation as soon as possible or to find a different language that could help; 2) occurrence of negative emotional condition, even the state of depression in case when communication goes on using the non-native language; 3) "fear of communication" with native speakers; 4) passive position (short answers, avoiding them); 5) the use of "body language"(A. Pease \& B. Pease, 2015) to demonstrate the lack of interest in the conversation; 6) unwillingness to create/invent words, the use of learned cliches and memorized phrases.

Clarification of the child's attitude to the language (s) at an early age (for example, using the program "RoadMapBilingual") and the objectification of this attitude through the family history and the "RoadMapBilingual" contributes to: a) individualization of approach to keeping / learning each of the languages of the child concerned; b) prevention of the recession of the language or complete rejection of communication using one particular language; c) defining of the family importance role and of an educational institution in each case separately, and correction of their interaction with the child and with each other.

What is to be done for testing of natural bilinguals? Is it advisable to test only one of the two (2L1 or native and non-native / the term and description of the shown situation in the European and American literature does not exist) languages? How detailed and realistic is the concept referring to being a bilingual, that can be derived from the test of his knowledge existing in his mind only due to one national culture? Take, for example, testing of the active and passive vocabulary (keeping in mind that the language is just a tool to reflect the extra-linguistic reality). Cards with pictures, divided into thematic groups are offered for the tested. The tester gives the tested a word stimuli. The task of the tested is to select and to pick up the appropriate definition and to present it to the examiner.

Example: http://images.pearsonclinical.com/images/Products/PPVT-IV/ppvt4.pdf

For testing RAF, RAN, RANN, RAAN (unifying principle for all test - Russian) 


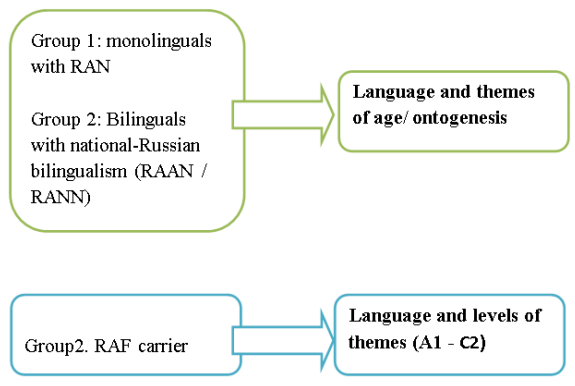

Figure 4. What is checked during testing RAF/RAN/RAAN (unifying principle for all test - Russian)

In the first case (Figure 4), it makes sense to compare the results of the test only in the first two groups of tested (to determine whether the language bilingual averaged typed-level language development of children / toddlers); since the topics corresponding to age division and topics of RAF levels are not the same.

In the second case (Figure 5) it is possible to juxtapose all the three groups tested for identification of the proficiency level of natural bilinguals by each native language in accordance with the same indicators of the native speakers as the only native ones.

The topics are selected correspondingly:

1) "home" topics (for example, furniture, kitchen utensils)

2) "neutral" topics which are shown in the conversation indoors and outdoors (for example, toys and clothes, food)

3) "outdoors" (kindergarten, school)" topics (e.g., school accessories, names of the subjects that are being studied).

The "family" language, used for communication at home (passively and actively) gets its own niche for estimation of the level, in comparison with the social language of the host country, "external social environment". Besides that, we get the opportunity to identify languages interaction (for example, we observe more frequent interference in the topics from the second group).

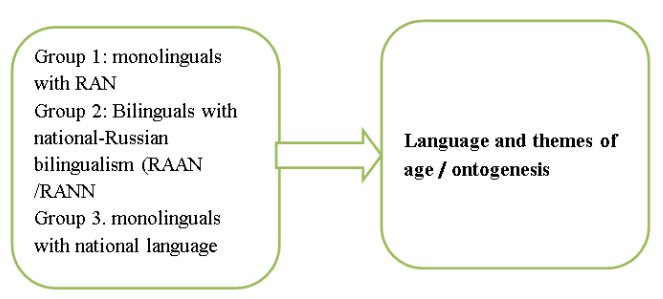

Figure 5. What is checked during testing proficiency in each of the languages of the bilingual (unifying principle - the age limit test)

Table 2. The main results. Consequently, we can view the following comparison Figure of RAN, RANN, RAAN, RAF (Montrul, 2008)

\begin{tabular}{|c|c|c|c|c|}
\hline Juxtaposition parameters & $\begin{array}{l}\text { RAN } \\
\text { (including national } \\
\text { districts of Russia) }\end{array}$ & $\begin{array}{l}\text { RAAN } \text { (the } \\
\text { Russian-speaking } \\
\text { diaspora in the } \\
\text { countries of the its } \\
\text { scattering) }\end{array}$ & $\begin{array}{l}\text { RANN } \\
\text { (migrants of the 2nd } \\
\text { generation in the } \\
\text { Russian Federation, } \\
\text { citizens from the former } \\
\text { republics of the USSR) }\end{array}$ & $\begin{array}{l}\text { RAF (including } \\
\text { foreigners learning } \\
\text { Russian in the RF) }\end{array}$ \\
\hline $\begin{array}{l}\text { Language sources (by } \\
\text { whom "the entry"is } \\
\text { introduced) }\end{array}$ & $\begin{array}{l}\text { The country's society and } \\
\text { family }\end{array}$ & Family & $\begin{array}{l}\text { Family and/or society } \\
\text { (the part of the society) }\end{array}$ & $\begin{array}{l}\text { Educational } \\
\text { organisation (for the } \\
\text { learners of the RAF in } \\
\text { the RF, society as } \\
\text { well) }\end{array}$ \\
\hline $\begin{array}{l}\text { The way of "the entry" and } \\
\text { communication at the }\end{array}$ & Oral & Oral & Oral or oral and written & Oral and written \\
\hline
\end{tabular}


initial stage

$\begin{array}{lllll}\text { The age of the entry into a } & \begin{array}{l}\text { Listening to the language } \\ \text { from the birth }\end{array} & \begin{array}{l}\text { Listening } \\ \text { language }\end{array} & \text { to } & \text { the } \\ \text { from } & \text { Various }\end{array}$
language birth
Depending on the country - usually from the age of 9 years old (at a specialized school where RAF is taught) and older

\begin{tabular}{|c|c|c|}
\hline $\begin{array}{l}\text { The purpose of entering } \\
\text { into the language }\end{array}$ & $\begin{array}{l}\text { Communication in all } \\
\text { spheres of life, } \\
\text { self-expression }\end{array}$ & $\begin{array}{l}\text { Communication with } \\
\text { the family member and } \\
\text { acquaitances (home, } \\
\text { domestic), } \\
\text { self-expression }\end{array}$ \\
\hline
\end{tabular}

Communication with

the family members (home and domestic) and / or society/part of the society (educational or professional

\begin{tabular}{ll}
\hline Norm-setting and & Spontaneity of the \\
spontaneity of entering the & original, at pre-school \\
language & and at school - \\
& normalization of material \\
& spontaneous meceived \\
& already receive
\end{tabular}

Spontaneity, often without the following normalization (the language is studied neither at school, nor and higher institution)

Communication with carriers of RAN (in the majority professional or educational area; for all who study in the RF - also domestic) Spontaneity from the Initial language very beginning, at learning with the help pre-school and school - of models and taking normalization and into account the deepening of already standards (for students spontaneously received in Russian Federation material(on the - with the presence of condition that the a natural spontaneous language is studied at component) pre-school and school of the region

\begin{tabular}{|c|c|c|c|c|}
\hline $\begin{array}{l}\text { What caused the selection } \\
\text { of the topics (age / } \\
\text { ontogeny, level of } \\
\text { knowledge) }\end{array}$ & $\begin{array}{l}\text { Age / ontogeny, topics } \\
\text { corresponding to this } \\
\text { particular age }\end{array}$ & $\begin{array}{l}\text { Age / ontogeny and the } \\
\text { situation } \\
\text { /communication sphere } \\
\text { (home, domestic) }\end{array}$ & $\begin{array}{l}\text { Age / ontogeny and the } \\
\text { situation } \\
\text { communication sphere }\end{array}$ & Levels of proficiency \\
\hline $\begin{array}{l}\text { Type of entry (mastering / } \\
\text { development / learning) }\end{array}$ & $\begin{array}{l}\text { The development, } \\
\text { (spontaneous) and } \\
\text { mastering (in accordance } \\
\text { with norm-setting) }\end{array}$ & $\begin{array}{l}\text { The development } \\
\text { (natural) and mastering } \\
\text { (in accordance with } \\
\text { norm-setting, with } \\
\text { further following } \\
\text { studies, if any) }\end{array}$ & $\begin{array}{l}\text { The development of } \\
\text { (natural) and } \\
\text { assimilation (rationing } \\
\text { in subsequent studies, if } \\
\text { any) }\end{array}$ & Studying \\
\hline
\end{tabular}

\begin{tabular}{|c|c|c|c|c|}
\hline $\begin{array}{l}\text { The presence of natural } \\
\text { language environment }\end{array}$ & $\begin{array}{l}\text { Yes, without any } \\
\text { restrictions }\end{array}$ & $\begin{array}{l}\text { Yes, at home and in the } \\
\text { diaspora }\end{array}$ & $\begin{array}{l}\text { Yes, at home and/or in } \\
\text { the society }\end{array}$ & $\begin{array}{l}\text { No (for those who study in } \\
\text { Russian Federation - yes) }\end{array}$ \\
\hline Levels of proficiency & Native language & $\begin{array}{l}\text { Speaking and auding in the } \\
\text { domestic environment - } \\
\text { similar to the native } \\
\text { language carriers (though } \\
\text { the richness and variability } \\
\text { of lexical structure is } \\
\text { behind); writing, reading - } \\
\text { from A1 to B2 (RAF) with } \\
\text { specific errors (due to the } \\
\text { interference } \\
\text { rusophonia) }\end{array}$ & Close to RAAN & $\begin{array}{l}\text { A1-C1 (C2 is achieved } \\
\text { seldom); } \\
\text { professional modules - up } \\
\text { to B2, C1 are rarely met }\end{array}$ \\
\hline $\begin{array}{l}\text { The probability of loss } \\
\text { (fossilization) }\end{array}$ & $\begin{array}{l}\text { Only in the case } \\
\text { of mental or } \\
\text { physical illness }\end{array}$ & $\begin{array}{l}\text { Complete loss usually is } \\
\text { impossible (except } \\
\text { deliberate suppression of } \\
\text { the language from the early } \\
\text { age); in case of termination } \\
\text { of a regular language } \\
\text { contacts with native } \\
\text { speakers - partial } \\
\text { fossilization or lack of } \\
\text { development }\end{array}$ & $\begin{array}{l}\text { Complete loss is } \\
\text { usually associated with } \\
\text { the suppression of } \\
\text { (deliberate) non-status } \\
\text { language from an early } \\
\text { age by the carrier as } \\
\text { well by } \\
\text { environmental } \\
\text { conditions in case of } \\
\text { termination of contacts } \\
\text { with native speakers - } \\
\text { partial fossilization or } \\
\text { lack of development }\end{array}$ & $\begin{array}{l}\text { Total loss is possible when } \\
\text { there is no regular } \\
\text { language communication } \\
\text { (no language environment } \\
\text { existing, no using of media } \\
\text { and etc.) }\end{array}$ \\
\hline $\begin{array}{l}\text { The quality of the } \\
\text { language }\end{array}$ & $\begin{array}{l}\text { Not limited by the } \\
\text { context of } \\
\text { familiar } \\
\text { situations, } \\
\text { constantly } \\
\text { expanding }\end{array}$ & $\begin{array}{l}\text { Restricted by the context of } \\
\text { domestic situations, if no } \\
\text { work is being done to } \\
\text { expand domestic context }\end{array}$ & $\begin{array}{l}\text { Limited by the context } \\
\text { (family) or educational } \\
\text { (public) situations, } \\
\text { if no aimed work is } \\
\text { being done to expand } \\
\text { domestic context }\end{array}$ & $\begin{array}{l}\text { Limited by the context of } \\
\text { studied/familiar situations }\end{array}$ \\
\hline $\begin{array}{l}\text { The scope and nature of } \\
\text { the language practice } \\
\text { (situations) }\end{array}$ & $\begin{array}{lr}\text { Wide range } & \text { of } \\
\text { aspects } & \text { in } \\
\text { different types of } \\
\text { situations and } \\
\text { areas } & \text { of } \\
\end{array}$ & $\begin{array}{l}\text { The practice of family } \\
\text { communication and } \\
\text { communication inside of } \\
\text { diaspora (when visiting the } \\
\text { Russian Federation the }\end{array}$ & $\begin{array}{l}\text { Practice is limited by } \\
\text { carriers of the Russian } \\
\text { language as non-native } \\
\text { in the family and /or } \\
\text { society }\end{array}$ & $\begin{array}{l}\text { Practice is limited (if } \\
\text { education takes place } \\
\text { outside of the Russian } \\
\text { Federation) by educational } \\
\text { context and by a standard }\end{array}$ \\
\hline
\end{tabular}




\begin{tabular}{|c|c|c|c|c|}
\hline & $\begin{array}{l}\text { communication } \\
\text { and also in } \\
\text { numerous } \\
\text { varieties of social } \\
\text { activities }\end{array}$ & $\begin{array}{l}\text { practice widens), the main } \\
\text { social role is of a junior } \\
\text { member in the family }\end{array}$ & & set of offered situations. \\
\hline $\begin{array}{l}\text { The scope and nature of } \\
\text { difficulties }\end{array}$ & $\begin{array}{l}\text { Possible lack of } \\
\text { vocabulary (due } \\
\text { to ontogeny and } \\
\text { environmental } \\
\text { social conditions), } \\
\text { the nature of } \\
\text { difficulties is also } \\
\text { defined by the } \\
\text { specifics of } \\
\text { ontogenesis }\end{array}$ & $\begin{array}{l}\text { The scope and nature of the } \\
\text { language practice define in } \\
\text { the majority of cases the } \\
\text { scope and nature of } \\
\text { difficulties in language } \\
\text { learning: keeping by the } \\
\text { teachers and parents the } \\
\text { ruling principle: } 1 \text { person - } \\
1 \text { language, consistency in } \\
\text { the use of languages, } \\
\text { increasing of situational } \\
\text { contexts, etc. The main } \\
\text { problems are associated } \\
\text { with "code switching" } \\
\text { (linguistic and behavioral), } \\
\text { the so-called interference at } \\
\text { all levels }\end{array}$ & Similar to RAAN & $\begin{array}{l}\text { The scope and nature of } \\
\text { difficulties are associated } \\
\text { with the volume and nature } \\
\text { of the language input into } \\
\text { the Russian language and } \\
\text { with the formation of the } \\
\text { communicative } \\
\text { competence in the } \\
\text { mother-tongue, and other } \\
\text { foreign languages of a } \\
\text { learner }\end{array}$ \\
\hline $\begin{array}{l}\text { The reasons for } \\
\text { difficulties (absence of } \\
\text { developed norms, } \\
\text { interference) }\end{array}$ & $\begin{array}{l}\text { Unformed } \\
\text { standards/ } \\
\text { norms }\end{array}$ & $\begin{array}{l}\text { Unformed standards/norms } \\
\text { and interference }\end{array}$ & $\begin{array}{l}\text { Unformed } \\
\text { standards/norms and } \\
\text { more rarely } \\
\text { interference }\end{array}$ & $\begin{array}{l}\text { Unformed standards/norms } \\
\text { and interference }\end{array}$ \\
\hline $\begin{array}{l}\text { The presence and nature } \\
\text { of word creation in the } \\
\text { language (languages, } \\
\text { between languages) }\end{array}$ & $\begin{array}{l}\text { Creation of words } \\
\text { is based on the } \\
\text { deliberate } \\
\text { violation of } \\
\text { linguistic norms } \\
\text { of the native } \\
\text { language (it lasts } \\
\text { throughout the } \\
\text { life }\end{array}$ & $\begin{array}{l}\text { Creation of words, (mostly } \\
\text { in the pre-school years) is } \\
\text { based on the juxtaposition } \\
\text { of languages; at an older } \\
\text { age it is also possible on } \\
\text { the same grounds }\end{array}$ & $\begin{array}{l}\text { Minimum amount of } \\
\text { word creation; may be } \\
\text { based on violation of } \\
\text { the norms of one } \\
\text { language, and the } \\
\text { juxtaposition } \\
\text { languages }\end{array}$ & $\begin{array}{l}\text { Creation of words in } \\
\text { Russian or with the use of } \\
\text { the Russian language is } \\
\text { practically absent }\end{array}$ \\
\hline $\begin{array}{l}\text { The presence and depth } \\
\text { of ethno-cultural context } \\
\text { (that is necessary for } \\
\text { understanding of a } \\
\text { subtext as well) }\end{array}$ & $\begin{array}{l}\text { Present, the depth } \\
\text { depends on the } \\
\text { level of general } \\
\text { education, } \\
\text { availability of } \\
\text { media } \\
\text { competence, etc. }\end{array}$ & $\begin{array}{l}\text { Present for each of the } \\
\text { cultures; for Russian - to } \\
\text { the extent that it is passed } \\
\text { by the older generation and } \\
\text { mastered independently } \\
\text { then (usually it is much } \\
\text { lower than the native } \\
\text { speakers' level) }\end{array}$ & $\begin{array}{l}\text { Present, approximately } \\
\text { on the same } \\
\text { basis/grounds as that } \\
\text { for RAAN }\end{array}$ & $\begin{array}{l}\text { Minimum due to the } \\
\text { impossibility of studying } \\
\text { "ethnosemantics", which is } \\
\text { received only as a result of } \\
\text { regular, permanent } \\
\text { contacts with native } \\
\text { speakers }\end{array}$ \\
\hline $\begin{array}{l}\text { Availability of language } \\
\text { competition }\end{array}$ & No & Yes & Yes & No \\
\hline
\end{tabular}

\section{Conclusion}

We think that time has come, when it became necessary to rank levels of language competences for different groups of population in various countries. For example, in bilingual Tatarstan, in which representatives of the Tatar, Russian and other native speakers of the world live, (due to functioning of free economic zones) teaching Russian and other languages (native, non-native, foreign) becomes very vital. That is why the precise definition of the criteria of competences formation becomes an actual issue.

It is possible to achieve significant results only following the described way: using a profound and accurate differentiation system for language proficiency levels and setting up of a proper educational training. Daniya Salimova and Hope Johnson definitely confirm that, "In any case, we can confidently assert that the bilingual and multilingual community of the twenty-first century, and specifically in connection to the intensifying momentum of the opening of borders and mobilization of culture and ethnicity, it is possible for an already advanced student to achieve fluent bilingualism even with domination of the native language (English) in a relatively short time: 100-120 hours of one-on-one lessons built on complex methodology rich with modern elements “. (Salimova \& Hope, 2014, p. 223)

And we would like to join the opinion: "Sometimes the acquisition of a new language can provide a person with the "right expression" for a particular sentiment, and thus can be used as a coping mechanism to express emotionally loaded experiences. ... a second language served as a vehicle to become more self regulated by finding ways to verbalize feelings that were once censored or restricted by external forces" (Imberti, 2007, 71). We would like to invite the readers also for helping and showing initiative - within the scope of our researches. (Peters \& Koudrjavtseva, 2014; Koudrjavtseva \& Volkova, 2014). 


\section{References}

Apresjan, J. D. (1974) Regular polysemy. Linguistics, 14(2), 5-32. http://dx.doi.org/10.1515/ling.1974.12.142.5

Berseneva, M. S., \& Kudryavtseva, E. L. (2013). About the terminology and practice of teaching Russian language in the world: Russian as a foreign, non-native and as another native language. Problems of modern literary education, 10, 181-195.

Burck, C. (2004). Living in several languages: implications for therapy. Journal of Family Therapy, 26, 323. http://dx.doi.org/10.1111/j.1467-6427.2004.00287.x

Gumboldt, A. von. (1964). On the difference between the structure of human language and its influence on the spiritual development of the human race. Readings on the history of linguistics XIX and XX centuries. History of Linguistics XIX-XX centuries in the essays and extracts (Part I, 3rd ed., pp. 233-411).

Hutmacher, W. (1997). Key competencies for Europe. Report of the Symposium Berne. Council for Cultural Co-operation (CDCC). Secondary Education for Europe Strasburg (p. 72). Retrieved January 15, 2015, from http://files.eric.ed.gov/fulltext/ED407717.pdf

Imberti, P. (2007). Exploring and understanding the Language Experience of the Non- English- Speaking Immigrant. Families in Society. The Journal of Contemporary Social Services, 71. http://dx.doi.org/10.1606/1044-3894.3593

Koudrjavtseva, E., \& Volkova, T. (2014). BILIUM-Bilingualism Upgrade Module (Part II): A comprehensive approach to teaching bilingual children language (non-native and another/second native) in the early childhood educational systems (ECES) of the European Union: A framework for an advanced training programme for pre-school teachers and similar structural units in mainstream schools (pupils from the age of 1.5 years to 5 years) - Riga: Retorika A.

Kudryavtseva, E. L. (2013a) History, present and basic concepts of linguistic-cultural tandems. Innovations in training of language (pp. 34-55.). International interuniversity scientific and methodical collection of articles. Almaty: Intern. Business Academy.

Kudryavtseva, E. L. (2013b). Online tandem as a way of creating a real communicative environment: from concept to the textbook. Collection of works of the International Forum conference "Media Education 2013".

Montrul, S. (2008). Incomplete Acquisition in Bilingualism. Re-examining the Age Factor (p. 312). Amsterdam: John Benjamins. http://dx.doi.org/10.1075/sibil.39

Pease, A., \& Pease, B. The Definitive Book of Body Language. Retrieved January 15, 2015, from http://www.peaseinternational.com/ebook/The\%20Definitive\%20Book\%20of\%20Body\%20Language\%20

Peters, H., \& Koudrjavtseva, E. (2014). BILIUM-Bilingualism Upgrade Module (Part I, p. 96). Riga: RetorikaA.

Rafieyan, V., Bin Abdul Majid, N., \& Eng, L.S. (2013). Relationship between Attitude toward Target Language Culture Instruction and Pragmatic Comprehension Development. English Language Teaching, 6(8), 125-132. http://dx.doi.org/10.5539/elt.v6n8p125

Rosaldo, R. (1989). Culture and truth: The remaking of social analysis (p. 288). Boston Beacon Press.

Salimova, D. A., \& Hope, J. (2014). Difficulties in the teaching of Russian as a foreign language: the perspectives of an ethnically Tatar specialist in Russian philology and an American student. Life Science Journal, 11(5s), 219-223. Retrieved from http://www.lifesciencesite.com

Snigireva, L. (2013). The Russian Language in Ireland: the Dialogue of Cultures. "Vestnik", Moscow City Pedagogical University. Scientific, Journal, Philological Education, 1(10), 136.

\section{Copyrights}

Copyright for this article is retained by the author(s), with first publication rights granted to the journal.

This is an open-access article distributed under the terms and conditions of the Creative Commons Attribution license (http://creativecommons.org/licenses/by/3.0/). 